American Journal of Biochemistry and Biotechnology 5 (1): 47-53, 2009

ISSN 1553-3468

(C) 2009 Science Publications

\title{
Plasmid Mediated Tolerance and Removal of Heavy Metals by Enterobacter sp
}

\author{
Bahig El-Deeb \\ Department of Biological Science, \\ Faculty of Science, Taif University, Taif, Saudia Arabia
}

\begin{abstract}
Problem statement: The role of plasmid in the heavy metal resistance and accumulation by endophytic bacteria was investigated. Approach: The experimental results showed that high level plasmid mediated $\mathrm{Cd}^{2+}$ and $\mathrm{Zn}^{2+}$ resistance in this strain is due to decreased $\mathrm{Cd}^{2+}$ and/or $\mathrm{Zn}^{2+}$ uptake/accumulation by resistance strain. Results: Based on the fact that subsequent plasmid curing experiments demonstrated that the ability to grow in presence of $\mathrm{Cd}^{2+}$ and $\mathrm{Zn}^{2+}$ was encoded by the 98 $\mathrm{kb}$ plasmid, whereas the ability to grow in presence of $\mathrm{Pb}^{2+}$ appeared to be encoded by the chromosome. The $\mathrm{Cd}^{2+}$ and $\mathrm{Zn}^{2+}$ removal capacity of the respective metal resistant strain (pBN4) were about 36 and $45 \mu \mathrm{g} \mathrm{g}^{-1}$ DW respectively, while the removal capacity of the both metal by sensitive variant showed a significant high $\mathrm{Cd}^{2+}$ and $\mathrm{Zn}^{2+}$ removal capacity of 153 and $228 \mu \mathrm{g} \mathrm{g}^{-1}$ DW respectively. Conclusion: The isolated endophytic Enterobacter was not only tolerant to heavy metals, but also bound considerable amount of heavy metals from the growth medium. The biosorbed order of the metals by parental strain and its cured derivatives strain based on the cell dry weight was found to be in the order of $\mathrm{Pb}^{2+}>\mathrm{Zn}^{2+}>\mathrm{Cd}^{2+}$.
\end{abstract}

Key words: Heavy metals, plasmid, Enterobacter sp., endophytic bacteria

\section{INTRODUCTION}

Contamination of the aquatic environment by toxic metal ions is a serious pollution problem ${ }^{[2,7,17]}$. Unlike organic pollutants, chemical or biological processes can not degrade toxic metal ions. To remediate the aquatic environment, the toxic metal ions should be concentrated in a form that can be extracted conveniently, possible for reuse or at least for proper disposal. Natural resources including plants and microorganisms are extensively explored to combat metal ion pollution.

Endophytic bacteria are described as nonpathogenic bacteria found within the interior tissues of healthy or symptomless plants ${ }^{[27]}$. These bacteria are found in most, if not all, plant species, span a wide range of bacterial phyla and are known to have plant growth promoting and pathogen control activities ${ }^{[8,9,25]}$. Recent research suggests that these beneficial impacts may, in the case of plant growing at contaminated sites, extent to the degradation of xenobiotic compounds $^{[1,6,30,32]}$.

Although endogenous bacterial endophytes capable of degrading hydrocarbons are likely to be widespread, to date only a few studies have assessed the heavy metal removal potential inherent to endophytic communities of heavy metal accumulator plant in phytoremediation. So, Soltan and Rashed ${ }^{[28]}$ found that bacterial strains isolated from root and stem tissues of different heavy metal accumulator plant growing at heavy metal contaminated sites were able to accumulate metals. The distribution of these bacteria was spatially limited both within and between the individual accumulator cultivars. Water hyacinth (Eichhornia crassipes) is one of the plant species that attracted considerable attention because of its ability to grow in heavily polluted water together with its capacity for metal ion accumulation ${ }^{[3,4,13,14,28,33]}$ though other studies have clearly manifested that hyacinths are more efficient in the phytoremediation of heavy metals ${ }^{[16,24,29]}$. We therefore hypothesized that Eichhornia crassipes tissues could be a potential habitat for metal-resistant microorganisms. Because certain microorganisms could enhance the growth and remediation potential of plants ${ }^{[1,3]}$ and because heavy metal-resistant microorganisms could be sources of genes for engineering plants for heavy metal resistance and remediation, our objective of the current study was to identify and characterize heavy metal resistant bacteria in the plant tissues of Eichhornia crassipes. Accordingly the aim of this work was to study the tolerance and the uptake of different heavy metals by endophytic bacteria isolated from heavy metal accumulator plant water hyacinth and to investigate the role of endogenous plasmid in metal resistant and removal potential by endophytic bacteria. 
Am. J. Biochem. \& Biotech., 5 (1): 47-53, 2009

\section{MATERIALS AND METHODS}

Bacterial strains: The bacterial strains and plasmids used in this study are listed in Table 1. Enterobacter sp. BN4 was originally isolated from surface sterilized leaves of Eichhornia crassipes growing on irrigation canals, Egypt ${ }^{[5]}$. The endophytic character of this strain was previously confirmed ${ }^{[5]}$ and identified as Enterobacter sp. based on the 16S rRNA gene sequence analysis. The sequences were deposited at Gen Bank (Enterobacter sp. Accession no. AM40578).

Chemical: Agarose and ethidium bromide were purchased from Sigma (St. Lous, MO, USA), Cadmium Chloride $\left(\mathrm{CdCl}_{2} \cdot \mathrm{H}_{2} \mathrm{O}\right)$, Zinc Chloride $\left(\mathrm{ZnCl}_{2}\right)$ and lead acetate $\mathrm{Pb} \quad(\mathrm{NO} 3)_{2}$ were procured from Merck (Darmstadt, Germany). Bacteriological media were purchased from Difco (Difco Laboratories, Detroit, Michigan) and Oxoid (Oxoid Inc., Nepean, Ontario). Chemical reagents used were of the highest grade commercially available

Media and growth condition: Strain BN4 and its derivatives were grown aerobically in Luria-Bertani (LB) medium ${ }^{[26]}$. For testing the degree of resistance to heavy metal salts, bacterial cells were grown at $30^{\circ} \mathrm{C}$ in a Tris-buffered Minimal Salts Medium (MSM) ${ }^{[11]}$. This medium was buffered with $50 \mathrm{mM}$ Tris- $\mathrm{HCl}$ (Trizma; Sigma), pH 7, instead of a phosphate buffer to avoid precipitation of insoluble metal phosphates. Phosphorus was added to the medium in the form of sodium $\beta$ glycerophosphate. This medium does not complex heavy metal cations. Analytical-grade salts of $\mathrm{CdCl}_{2} \cdot \mathrm{H}_{2} \mathrm{O}, \mathrm{Pb}(\mathrm{NO} 3)_{2}$ and $\mathrm{ZnCl}_{2}$ were used to prepare $1.0 \mathrm{M}$ stock solution, which were sterilized by autoclaving and added to MSM media for determination of the minimum inhibitory concentrations (MICs) of the metal ions for each isolate. The range of concentrations used was $0.5-5 \mathrm{mM}$ for lead nitrate, $0.5-5 \mathrm{mM}$ for zinc chloride and 0.1-3 $\mathrm{mM}$ for cadmium chloride. Overnight cultures grown in LB Broth were diluted to $10^{-5}$ cells $\mathrm{mL}^{-1}$ then spotted onto LB agar plates or MSM agar plates. Duplicate plates of each isolate were incubated at $28^{\circ} \mathrm{C}$ for 3 days before growth was scored and MIC (the lowest concentration of metal that completely prevented growth) determined.

Antibiotic resistance: Antibiotic resistance was tested, using Nutrient agar containing tetracycline $\left(20 \mu \mathrm{g} \mathrm{mL}^{-1}\right)$, kanamycin $\left(100 \mu \mathrm{g} \mathrm{mL}^{-1}\right)$, ampicillin $\left(100 \mu \mathrm{g} \mathrm{mL}^{-1}\right)$ or chloramfenicol $\left(25 \mu \mathrm{g} \mathrm{mL} \mathrm{mL}^{-1}\right.$ ), which then added aseptically to the medium after autoclaving. Cultures were incubated at $30^{\circ} \mathrm{C}$ for 7 days.
Table 1: Bacterial strains and plasmids used in this study

\begin{tabular}{|c|c|c|}
\hline Strains or plasmid & Relevant characteristic(s)a & Reference or source \\
\hline Enterobacter $\mathrm{sp}$. & & $\begin{array}{l}\text { Accession no. } \\
\text { AM40578 This studv }\end{array}$ \\
\hline BN4 & $\begin{array}{l}\mathrm{Km}^{\mathrm{r}}, \mathrm{Tet}^{\mathrm{r}}, \mathrm{Amp}^{\mathrm{r}}, \mathrm{Cd}^{\mathrm{r}}, \mathrm{Zn}^{\mathrm{r}}, \\
\mathrm{Pb}^{\mathrm{r}} \text { wild type BN4, pBN4 } \\
\text { carrier }\end{array}$ & \\
\hline BN4 M & $\begin{array}{l}\mathrm{Km}^{\mathrm{s}}, \mathrm{Amp}^{\mathrm{s}} \mathrm{Cd}^{\mathrm{s}}, \mathrm{Zn}^{\mathrm{s}} \mathrm{a} \\
\text { cured mutant of BN4, plasmidless }\end{array}$ & This study \\
\hline BN4T & $\begin{array}{l}\mathrm{Km}^{\mathrm{r}}, \mathrm{Amp}^{\mathrm{r}}, \mathrm{Cd}^{\mathrm{r}}, \mathrm{Zn}^{\mathrm{r}} \\
\text { transconjugant by mating of } \\
\text { BN4 and BN4M, pBN4 carrier }\end{array}$ & This study \\
\hline $\begin{array}{l}\text { Plasmids } \\
\text { pBN4 }\end{array}$ & $\begin{array}{l}98 \mathrm{~Kb} \mathrm{Km}^{\mathrm{r}}, \mathrm{Amp}^{\mathrm{r}}, \mathrm{Cd}^{\mathrm{r}}, \mathrm{Zn}^{\mathrm{r}}, \\
\text { heavy metal resistant plasmid } \\
\text { of Enterobacter } \mathrm{sp} \mathrm{BN} 4\end{array}$ & This study \\
\hline
\end{tabular}

Plasmid isolation: Plasmid DNA was isolated from endophytic bacteria essentially by the procedure of Kado and $\mathrm{Liu}^{[15]}$. The isolated plasmid was characterized by agarose gel electrophoresis according to the standard procedure of Sambrook et al. ${ }^{[26]}$. Agarose gel electrophoresis through a horizontal slab gel of $0.8 \%$ agarose submersed in TBE (Tris- $\mathrm{HCl}$, Boric acid, EDTA) running buffer at $70 \mathrm{~V}$ for $2 \mathrm{~h}$ were performed. DNA bands were stained with ethidium bromide for $15 \mathrm{~min}$. and visualized on a UV transilluminator. Molecular weight of the plasmids were determined by using a computer program (DNA size Version 1) ${ }^{[21]}$.

Curing and conjugation: To determine if the resistance genes are encoded by a plasmid or not, Mitomycin $\mathrm{C}$ was used to eliminate the plasmid from the strain. Bacterial strain was grown on LB broth containing various concentrations of mitomycin $\mathrm{C}(5$, 10 and $20 \mu \mathrm{g} \mathrm{mL}^{-1}$ ) on a rotary shaker at $30^{\circ} \mathrm{C}$ for $48 \mathrm{~h}$. Appropriate dilutions were spread on LB agar plates. Single colonies were replicated onto nutrient agar supplemented with different heavy metals. Heavy metal sensitive colonies were scored and reported as percent cured. Cured isolates were then reinoculated into MSM with and without metals stress to reevaluate the MIC of each isolate to each metal. For conjugal gene transfer, overnight cultures of donor strain Enterobacter sp. BN4 and of the BN4M recipient strain were mixed (1:1) and incubated at $28^{\circ} \mathrm{C}$. After overnight growth, the bacteria were suspended in saline $\left(9 \mathrm{~g}\right.$ of $\left.\mathrm{NaCl} \mathrm{L}^{-1}\right)$, diluted and plated onto selective media and several dilutions were plated on minimal medium agar supplemented with heavy metals.

Inducibility of heavy metal resistance of strain BN4: A Tris-glucose medium was used to study the inducibility of cadmium, zinc and lead. The pre-cultures were prepared by the inoculation of BN4 in $10 \mathrm{~mL}$ of the Tris-glucose medium and left to grow overnight at 
$30^{\circ} \mathrm{C}$ on a rotary shaker $(100 \mathrm{rpm})$. For the induction, $0.1 \mathrm{~mL}$ of this culture was then added to a $100 \mathrm{~mL}$ Erlenmeyer flask containing $10 \mathrm{~mL}$ of the Tris-glucose medium with and without heavy metals (e.g. $0.05 \mathrm{mM}$ $\mathrm{Cd}^{2+}, 0.05 \mathrm{mM} \mathrm{Zn}^{2+}$, or $0.05 \mathrm{mM} \mathrm{Pb}^{2+}$ ) and incubated at $30{ }^{\circ} \mathrm{C}$ on shaker for $18 \mathrm{~h}$. These cultures were then used to inoculate $50 \mathrm{~mL}$ media containing sub-inhibitory concentrations of the heavy metals $\left(1 \mathrm{mM} \mathrm{Cd}^{2+}\right.$, $1.5 \mathrm{mM} \mathrm{Zn}^{2+}$ or $1.5 \mathrm{mM} \mathrm{Pb}^{2+}$ ) and incubated at $30^{\circ} \mathrm{C}$ with shaking. The growth of bacteria was monitored periodically by measuring the optical density at $600 \mathrm{~nm}$.

Analysis of Metal removal: $\mathrm{Cd}^{2+}, \mathrm{Zin}^{2+}$ and/or $\mathrm{Pb}^{2+}$ uptake by growing cells was determined at $0.1 \mathrm{mM}$ of tested metals by the parental strain and its cured derivative. The cells were grown in nutrient broth supplemented with desired concentration of metals at $30^{\circ} \mathrm{C}$ with $150 \mathrm{rpm}$. After $24 \mathrm{~h}$ the bacterial were collected, washed and dried at $55^{\circ} \mathrm{C}$ for $24 \mathrm{~h}$. After acid digestion (nitric acid: Perchloric acid, 5:3), metal concentration in both washed fluid and pellet were determined using an atomic absorption spectrophotometer (Perkin Elmer analyst 300). Determination of cadmium, zinc and lead was done by using a specific lamp for each metal and at specific wavelengths. All of the metal removal experiments were conducted in triplicate and mean values were used in the analysis of data.

\section{RESULTS}

Heavy metal and antibiotic resistance: MIC of various metals for Enterobacter sp. BN4 are shown in Table 2. $\mathrm{Zn}^{2+}$ and $\mathrm{Pb}^{2+}$ were less toxic towards Enterobacter cells than $\mathrm{Cd}^{2+}$. The order of the metals toxicity to the bacterium was found to be $\mathrm{Cd}^{2+}>$ $\mathrm{Zn}^{2+}>\mathrm{Pb}^{2+}$. The resistance to antibiotics was also examined for metal tolerant BN4. It was found to be resistance to tetracycline $\left(20 \mu \mathrm{g} \mathrm{mL} \mathrm{m}^{-1}\right)$, kanamycin $\left(100 \mu \mathrm{g} \mathrm{mL}^{-1}\right)$ and ampicillin $\left(100 \mu \mathrm{g} \mathrm{mL}^{-1}\right)$.

Genetic localization of cadmium, zinc and lead resistance in the endophytic bacteria $\mathrm{BN4}$ :

Plasmid content: The plasmid isolated from BN4 was designated as pBN4. The estimated size of the plasmids was approximately $98 \mathrm{~Kb}$ (Fig. 1, Lane 1, 3). The location of heavy metal resistance genes on plasmid DNA was determined by plasmid curing and conjugation experiments.

Plasmid curing: To examine the correlation between resistant to cadmium, zinc and lead and the presence of
$\mathrm{pBN} 4$, mitomycin $\mathrm{C}$ was used to cure strain $\mathrm{BN} 4$ from its plasmid $\mathrm{pBN} 4$. The loss of resistance to $\mathrm{Cd}^{2+}, \mathrm{Zn}^{2+}$, or $\mathrm{Pb}^{2+}$ in cured strains was used as an indicator of curing (Table 2). Out of three handed Enterobacter sp. (BN4) transformants, 200 colonies were cured, showing $66 \%$ curing efficiency.

The comparison of resistance before and after curing is shown in Table 2. This was taken as an indication of curing of the plasmids. The results showed that while the BN4 resisted $\mathrm{Cd}^{2+}, \mathrm{Zn}^{2+}$ and $\mathrm{Pb}^{2+}$, it could not grow on medium containing $\mathrm{Cd}^{2+}$ and $\mathrm{Zn}^{2+}$ after curing. This strain showed a growth on medium containing $\mathrm{Pb}^{2+}$ before and after curing. Similarly, the antibiotic resistance of uncured and cured cultures of the isolate was also compared to determine the location of antibiotic resistance genes. The results showed that while the BN4 resisted to Kanamycin and ampicillin, it could not grow on medium containing these antibiotics after curing. To confirm if the resistance genes are encoded by this plasmid, the electrophoretic profile of the plasmid isolated from the original (non-cured) strain was compared with the cured strain. The results of this experiment indicates that each of cadmium and zinc and/or antibiotic-sensitive mutant lost the plasmid pBN4 (Fig. 1; Lane 1). One of these mutants was designated as BN4M.

Table 2: MICs of heavy metals for Enterobacter sp. BN4 and its derivatives in different cultural conditions

\begin{tabular}{|c|c|c|c|c|c|c|}
\hline \multirow{2}{*}{$\begin{array}{l}\text { Bacterial } \\
\text { strains }\end{array}$} & \multicolumn{2}{|c|}{ MIC of $\mathrm{Cd}^{2+}(\mathrm{mM})$} & \multicolumn{2}{|c|}{ MIC of $\mathrm{Zn}^{2+}(\mathrm{mM})$} & \multicolumn{2}{|c|}{ MIC of $\mathrm{Pb}^{2+}(\mathrm{mM})$} \\
\hline & MSM & LB & MSM & LB & MSM & LB \\
\hline $\mathrm{BN} 4$ & 2.1 & 3.0 & 4.0 & 5.0 & 4.8 & 6.0 \\
\hline BN4M & 0.3 & 0.6 & 0.5 & 0.7 & 3.6 & 5.8 \\
\hline BN4T & 2.1 & 3.0 & 4.0 & 5.0 & 4.8 & 6.0 \\
\hline
\end{tabular}

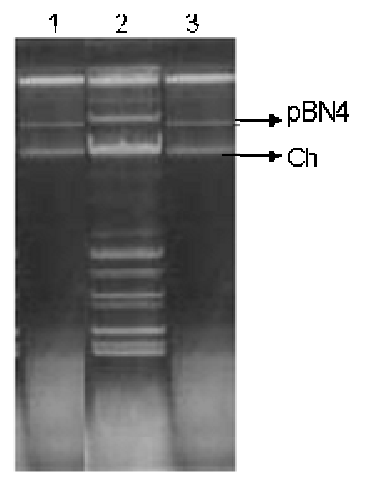

Fig. 1: Plasmid profile of strain $\mathrm{BN} 4$ and its derivatives. (Lane 1), wild type strainBN4; (Lane 2), Shigella flexneri 49 used as size standard: (Lane 3), BN4T transconjugant obtained by mating of BN4 and BK4M, Ch; chromosomal DNA 
Plasmid conjugation: Wild type strain BN4 was used as a donor of pBN4 plasmid to ensure that cadmium and zinc resistance genes are located on this plasmid. The strain BN4M was marked to be rifampin resistance (data not shown) and was used as a recipient strain. All obtained transconjugants were true rifampin resistance. These transconjugants acquired the resistance to $\mathrm{Cd}^{2+}$ and $\mathrm{Zn}^{2+}$ and contained a plasmid were shown to be identical to pBN4 by agarose gel electrophoresis (Fig. 1; Lane 3). The frequency of plasmid transfer from BN4 to $\mathrm{BN} 4 \mathrm{M}$ ranged from $2 \times 10^{-5}$ per recipient cell.

MIC comparison between wild type strain and its derivatives: Examination of growth of the plasmid bear strain BN4 and its cured derivative on different medium compositions containing varied concentrations of heavy metals showed variable degrees of resistance to one or more of three metals: Cadmium, zinc and lead (Table 2). On rich medium (LB), wild type strain BN4 (pBN4) exhibited high resistance to cadmium and zinc in comparison with the cured strain (Table 2). However, the MICs of $\mathrm{Pb}^{2+}$ for the wild type strain and its cured derivative were very close (Table 2). Tris-buffer was not utilized as a carbon or nitrogen sources by the tested strains (data not shown). In the present study, the level of cadmium, zinc and lead resistance in strains BN4 and its cured strain BN4M when grown on Tris-medium amended with glucose as sole carbon and energy source was determined. As reported in Table 2, the MIC of $\mathrm{Cd}^{2+}$ for the sensitive cured strain was $0.1 \mathrm{mM}$, whereas the MICs for wild type strains (BN4) were $2 \mathrm{mM}$. Furthermore, Strain BN4 exhibited the highest level of resistance to zinc ( $3 \mathrm{mM})$, although its resistance level was much higher than that of sensitive strain (Table 2). The results in Table 2 showed that no great difference among the MICs of $\mathrm{Pb}^{2+}$ for the tested strains.

Regulation of heavy metal resistance genes in BN4: Whether the $\mathrm{Cd}^{2+}, \mathrm{Zn}^{2+}$, or $\mathrm{Pb}^{2+}$ resistance property in strain BN4 is inducible or constitutive was determined by examining the growth curves. Figure 2 shows that, the induced and uninduced cells passed a lag period of $6 \mathrm{hr}$ indicating that the $\mathrm{pb}$ in strain $\mathrm{BN} 4$ is constitutively expressed. In contrast, the cells of this strain pre-grown in the presence of $\mathrm{Cd}^{2+}$ or $\mathrm{Zn}^{2+}$, started to grow after a shorter lag phase than the uninduced cells (Fig. 2).

Heavy metal removal by endophytic bacteria BN4 and its cured derivative: The heavy metal-resistant endophytic strain BN4 and its cured derivative BN4M were tested for their ability to remove cadmium, zinc and/or lead from the growth medium.

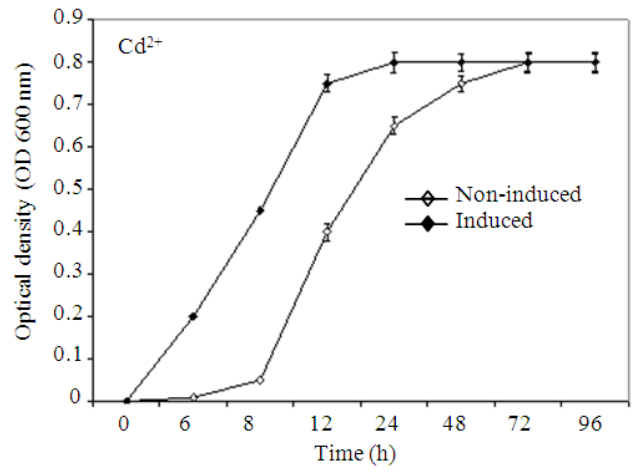

(a)

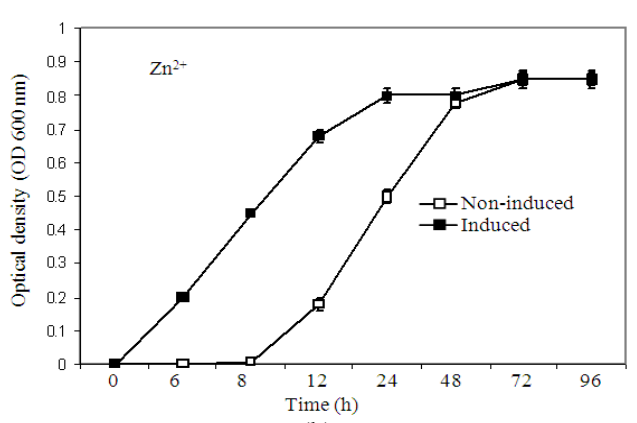

(b)

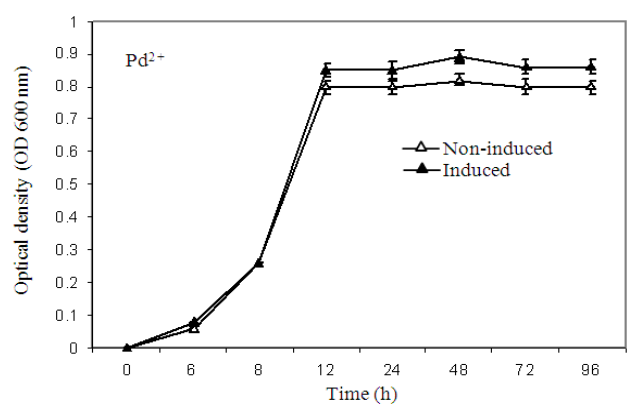

(c)

Fig. 2: Growth of Enterobacter sp. strain $\mathrm{BN} 4$ in presence of $1 \mathrm{mM} \mathrm{CdCl} 2,1.5 \mathrm{mM} \mathrm{ZnCl}_{2}$ and $1.5 \mathrm{~Pb}\left(\mathrm{NO}_{3}\right)_{2}$. Cells were induced by overnight growth in presence of $50 \mu \mathrm{M} \mathrm{Cd}, \mathrm{Zn}$, or $\mathrm{Pb}$

The parental strain and its cured derivative were grown in the presence of $0.1 \mathrm{mM}$ of each metal. Metals which loosely bound with cells (in washing) and accumulated metal in the cells were determined. Curing of plasmid in the parental strain resulted in substantial increase in $\mathrm{Cd}^{2+}$ and/or $\mathrm{Zn}^{2+}$ uptake (both accumulated and loosely bound $\mathrm{Zn}^{2+}$ or $\mathrm{Cd}^{2+}$ ) (Fig. 3). However, the accumulated and loosely bound $\mathrm{Pb}^{2+}$ uptake were the same in the parental strain and its cured derivative (Fig. 3). 


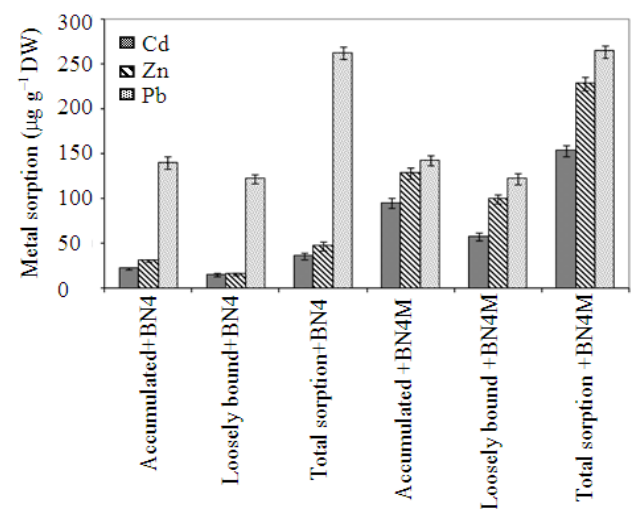

Fig. 3: Cadmium, zinc and lead uptake as accumulated, loosely bound and total metal sorption by metal resistant strain $\mathrm{BN} 4$ and its cured derivative $\mathrm{BN} 4 \mathrm{M}$

\section{DISCUSSION}

The differences between MIC of either wild type strain or its derivatives on rich medium or Tris medium could be explained by those mentioned previously by Mergeay et $a l .{ }^{[19]}$ They demonstrated that the interference of high phosphate content in usual minimal medium with metals effect, can lead to overestimation of the $\mathrm{MIC}^{[19]}$. In comparison to previous studies on the metal tolerance of endophytic Enterobacter sp. ${ }^{[27]}$, the endophytic bacterium isolated in the present study exhibited more resistance (in Tris medium and at $\mathrm{pH} 7$ ) to $\mathrm{Cd}^{2+}, \mathrm{Zn}^{2+}$ and $\mathrm{Pb}^{2+}$. A direct comparison of these MIC estimates with those reported by other authors is not conclusive. These discrepancies in the MIC results could be resulting in differences in the metal-binding capacities of the media used. However, the MIC estimated for Enterobacter sp. BN4 for $\mathrm{Cd}^{2+}, \mathrm{Zn}^{2+}$ and/or $\mathrm{Pb}^{2+}$ in Tris medium as well as the MIC of the same metals for BN4 in rich medium, were at levels regarded as those typical for metal resistant species ${ }^{[18-20]}$. Multiple antibiotic resistance shown by isolate BN4 might be associated with heavy metals resistance. In many studies, the association between metal tolerance and antibiotic resistance have been reported ${ }^{[27]}$. It has been suggested that under environmental conditions of metal stress, metal and antibiotic resistant microorganisms will adapt faster by the spread of Rfactors than by mutation and natural selection ${ }^{[32]}$.

Enterobacter BN4 was able to grow at high concentrations of $\mathrm{Cd}^{2+}, \mathrm{Zn}^{2+}$ and $\mathrm{Pb}^{2+}$ in liquid medium, which might be important for the capacity of this bacterium to survive in different source of pollution with elevated heavy metal levels. It was found that the toxicity of $\mathrm{Cd}^{2+}$ was higher than that of $\mathrm{Zn}^{2+}$ and $\mathrm{Pb}^{2+}$, that consistent with the results in solid media in the present study and many other reports ${ }^{[27]}$. This difference in toxicity could be explained by the conditions of the isolation and selectivity of microbial culture techniques adopted in each study, particularly with respect to the nature and specificity of growth media ${ }^{[18-20]}$. These results also indicating that cadmium and zinc resistance in strain BN4 are inducible expressed whereas, lead is constitutively expressed. Similar observations have been reported by others ${ }^{[11,12]}$ in which $\mathrm{Cd}^{2+}$ and $\mathrm{Zn}^{2+}$ resistance genes were induced in Pseudomonas putida.

Metal-tolerant bacteria have evolved various resistance and detoxification mechanisms ${ }^{[10,19,20]}$. The resistance mechanisms are chromosomally encoded or, more often, plasmids of different size and showing conjugative capabilities are carriers of metal-resistance genes $^{[31]}$. Curing of the plasmid in the isolated strain was done by using mitomycin $\mathrm{C}$ in order to determine the presence of metal ion resistance genes on plasmid or chromosomal DNA. This study also revealed the high efficiency of mitomycin $\mathrm{C}$ in curing the plasmid. Cured and uncured cultures were compared for their resistance against metal ions and antibiotics. The comparison clearly showed the tolerance to $\mathrm{Zn}^{2+}$ and $\mathrm{Cd}^{2+}$ appeared to be associated with plasmid, as confirmed by the conjugation data. However, Lead resistance gene was shown to be present on the chromosomal DNA rather than the plasmid DNA as the cured and uncured cultures remained similar in $\mathrm{Pb}^{2+}$ resistance. Previously, Piotrowska-Seget et al. ${ }^{[20]}$ reported that resistance to toxic metals $\left(\mathrm{Zn}^{2+}\right.$ and $\left.\mathrm{Cd}^{2+}\right)$ have been found in bacteria from clinical and environmental origins and genetics determinant of resistance are frequently located on plasmids or transposons. In contrast, Roan ${ }^{[22]}$ and Roan and Kellog ${ }^{[23]}$ did not find plasmids in $\mathrm{Pb}^{2+}$-resistance isolates collected from contaminated soils. Similar report was presented by $\mathrm{Haq}$ et $a l .{ }^{[10]}$, for loss of plasmid linked drug resistance after treatment curing agent. Here I found that curing with mitomycin C resulted in loss ampicillin and kanamycin resistance in BN4 strain. The location of resistance genes for antibiotics, metal resistance on plasmid of Enterobacter sp. BN4 was confirmed by conjugation of BN4M mutant and cured BN4, whereby the transconjugants showed all characteristic of wild type strain BN4.

Wild type BN4 and its cured derivatives isolated in this study show different efficiencies in removal of $\mathrm{Cd}^{2+}, \mathrm{Zn}^{2+}$ and $\mathrm{Pb}^{2+}$ from the medium. They accumulated a significant amount of these metals within $24 \mathrm{~h}$. The accumulation fraction of $\mathrm{Cd}^{2+}$ and/or $\mathrm{Zn}^{2+}$ was more relative to loosely bound one either in parental or cured derivative. A comparison of parental strains and its cured derivative exhibited that with the loss of plasmid, $\mathrm{Cd}^{2+}$ and $\mathrm{Zn}^{2+-}$ sorption (accumulated and loosely bound) of bacterial strains increased 4 and 6 fold, respectively (Fig. 3). These results reflected that high level plasmid mediated $\mathrm{Cd}^{2+}$ and $\mathrm{Zn}^{2+}$ resistance in 
this strain is due to decreased $\mathrm{Cd}^{2+}$ and/or $\mathrm{Zn}^{2+}$ uptake/accumulation by resistance strain.

Plasmid-determined reduced accumulation of $\mathrm{Cd}^{2+}$ have been described in Pseudomonas putida ${ }^{[12]}$. Roan and Kellogg ${ }^{[23]}$ observed that different strains of Cdresistant bacterial isolates varied in their resistance level due to potentially varied mechanism of resistance. Significant reduction of soluble $\mathrm{Cd}^{2+}$ was observed during growth of plasmid-bearing Bacillus strain H9 and Pseudomonas H1. Similarly, three strains of bacteria isolated from industrial effluents (Enterobacter cloacae and Klebsiella spp.) were resistant to high concentrations of $\mathrm{Cd}^{2+}, \mathrm{Pb}^{2+}$ and $\mathrm{Cr}^{2+}$ in the growth media and could remove approximately $85 \% \mathrm{Cd}^{2+}$ during growth ${ }^{[10]}$. Further, the $\mathrm{Cd}^{2+}, \mathrm{Zn}^{2+}$ and $\mathrm{Pb}^{2+}$ removal efficiency was growth-phase dependent. This result implicated the advantage of plasmid-encoded $\mathrm{Cd}^{2+}$ and $\mathrm{Zn}^{2+}$ resistance genes, allowing for further genetic manipulation and enhanced efficiency.

\section{CONCLUSION}

In view of the results of metal accumulation experiments, it was concluded that endophytic isolate was not only tolerant to heavy metals, but also bound considerable amount of heavy metals from the growth medium. The biosorbed order of the metals by parental strain and or its cured derivatives strain based on the cell dry weight was found to be in the order of $\mathrm{Pb}^{2+}>$ $\mathrm{Zn}^{2+}>\mathrm{Cd}^{2+}$.

Conjugation frequency of $\mathrm{Cd}^{2+}$ and $\mathrm{Zn}^{2+}$ resistance genes suggests that horizontal gene transfer may be an important factor for the development of metal resistance microorganisms in the environment and may be linked to the distribution of these resistances in nature.

\section{REFERENCES}

1. Barac, T., S. Taghavi, B. Borremans, A. Provoos, L. Oeyen, J.V. Colpaert, J. Vangronsveled and D. Vander Lelie, 2004. Engineered endophytic bacteria improve phytoremediation of water soluble, volatile, organic pollutants. Nat. Biotechnol., 22: 583-588. http://www.ncbi.nlm.nih.gov/pubmed/15077119

2. Blackmore, G., 1998. An overview of trace metal pollution in coastal waters of Hong Kong. Sci. Total Environ., 214: 21-48. http://www.ncbi.nlm.nih.gov/pubmed/9646516

3. Burd, G.I., D.G. Dixon and B.R. Glick, 1998. Plant growth promoting bacterium that decreases nickel toxicity in seedlings. Applied Environ. Microbiol., 64: 3663-3668.

http://www.ncbi.nlm.nih.gov/pubmed/9758782
4. Cordes, K.B., A. Mehra, M.E. Farago and D.K. Banerjee, 2000. Uptake of $\mathrm{Cd}, \mathrm{Cu}, \mathrm{Ni}, \mathrm{Zn}$ by water hyacinth, Eichhornia crassipes (Mart) Sloms from Pulverized Fuel Ash (PFA) leachates and slurries. Environ. Geochem. Health, 22: 297-316. DOI: 10.1023/A:1006795631827

5. El-deeb, B.A., H. El-Sharouny and N. Fahmy, 2006. Plasmid incidence, antibiotic and heavy metal resistance patterns of endophytic bacteria isolated from aquatic plant, Eichhornia crassipes. Assiut. Univ. J. Botany, 33: 151-171.

6. Germaine, K.J., X. Liu, G. Garcia Cabellos, J.P. Hogan, D. Ryan and D.N. Dowling, 2006. Bacterial endophytes-enhanced phytoremediation of the organochlorine herbicide 2,4dichlorophenoxyacetic acid. FEMS. Mirobiol. Ecol., 57: 302-310.

http://cat.inist.fr/?aModele $=$ afficheN\&cpsidt $=17941311$

7. Glass, D.J., 2000. Economic Potential of Phytoremediation. In: Phytoremediation of Toxic Metals Using Plants to Clean Up the Environment, Raskin, I. (Ed.). John Wiley, New York, ISBN: 047-119254-6, pp: 15-32.

8. Hallmann, J., A. Quadt-Hallmann, W.F. Mahaffee and J.W. Kloepper, 1997. Bacterial endophytes in agricultural crops. Can. J. Microbiol., 43: 895-914. http://direct.bl.uk/bld/PlaceOrder.do?UIN=037524 761\&ETOC $=$ RN\&from $=$ searchengine

9. Hallmann, J. and G. Berg, 2006. Spectrum and Population Dynamics of Bacterial Roots Endophytes. In: Microbial Root Endophytes, Schulz, B.J.E., C.J.C. Boyle and T.N. Sieber (Eds.). Springer-Verlag, Berlin, pp: 15-31.

10. Haq, R., S.K. Zaidi and A.R. Shakoori, 1999. Cadmium resistant Enterobacter cloacae and Klebsiella sp. Isolated from industrial effluents and their possible role in cadmium detoxification. World J. Microbiol. Biotechnol., 15: 249-254. http://cat.inist.fr/?aModele=afficheN\&cpsidt $=1972997$

11. Higham, P.D., P.J. Sadler and M.J. Scawen, 1984. Cadmium-resistant Pseudomonas putida synthesizes novel cadmium proteins. Science, 225: 1043-1046. http://www.ncbi.nlm.nih.gov/pubmed/17783048

12. Ingole, N.W. and A.G. Bhole, 2003. Removal of heavy metals from aqueous solution by water hyacinth (Eichhornia crassipes). J. Water Supply Res. Technol. AQUA., 52: 119-128. http://direct.bl.uk/bld/PlaceOrder.do?UIN=128079 610\&ETOC $=$ RN\& from $=$ searchengine

13. Ismail, A.S., M.F. Abdel-Sabour and R.M. Radwan, 1996. Water hyacinth as an indicator for heavy metals pollution in different selected sites and water bodies around Greater Cairo [Egypt]. J. Soil Sci., 36: 343-354.

http://www.fao.org/agris/search/display.do?f=./199 8/v2408/EG1998000759.xml;EG1998000759 
14. Jamil, K., G. Salifakala and K.B. Mahesh, 1998. Removal of Toxic Metals from Industrial Effluents by Aquatic Plants. In: Advances in Wastewater Treatment Technologies, Trivedy, R.K. (Ed.). Gobal Science, Aligarh, pp: 7-11. ISBN: 527319018

15. Kado, C.I. and S.J. Liu, 1981. Rapid procedure for detection and isolation of large and small plasmids. J. Bacteriol., 145: 1365-1373. http://www.ncbi.nlm.nih.gov/pubmed/7009583

16. Kelley, C., J.A. Curtis, J.K. UNO and C.L. Berman, 2000. Spectroscopic studies of the interaction of Eu (III) with the roots of water hyacinth. Water Air Soil Pollut., 119: 171-176. http://cat.inist.fr/?aModele $=$ afficheN\&cpsidt $=1339$ 304

17. Khamar, M., D. Bouya and C. Ronneau, 2000. Metal pollution and organic loading of water and sediments in the aquatic system of morocco by the discharge of urban wastewater. Water Q. Res. J. Canada, 35: 147-161. http://md1.csa.com/partners/viewrecord.php?reque ster $=$ gs \& collection $=E N V \&$ recid $=4665599 \& q=$ Kha mar\%2C+M.D.+and+C.+Ronneau\%2C+2000.+\&u $\mathrm{id}=1301244 \&$ setcookie $=$ yes

18. Mergeay, M., 1995. Heavy Metal Resistances in Microbial Ecosystems. In: Molecular Microbiol Ecology Manual, Akkermans, A.D.L., F.J. De Bruijn, J.D. Van Elsas and J.T. Trevors (Eds.). Kluwer Academic Publishers, Dordrecht, ISBN: 9780792364788, pp: 1-7.

19. Mergeay, M., D. Nies, H.G. Schiegel, J. gerits, P. Charles and F. Van Gijsegem, 1985. Alcaligenes eutrophus $\mathrm{CH} 34$ is a facultative chemolithotroph with plasmid-bound resistance to heavy metals. J. Bacteriol., 162: 238-334. http://www.ncbi.nlm.nih.gov/pubmed/3884593

20. Seget, P.Z., J. Cycoń and J. Kozdrój, 2005. Metaltolerant bacteria occurring in heavily polluted soil and mine spoil. Applied Soil Ecol., 28: 237-246. http://cat.inist.fr/?aModele $=$ afficheN\&cpsidt $=1645$ 8841

21. Raghava, G.P.S., 2001. A web server for computing the size of DNA/protein fragments using a graphical method. Biotechnol. Software Internet Report, 5: 198-200. DOI: 10.1089/152791601753304402

22. Roane, T.M., 1999. Lead resistance in two bacterial strains from heavy metal contaminated soils. Microbial Ecol., 37: 218-224.

23. Roane, T.M. and S.T. Kellogg, 1996. Characterization of bacterial communities in heavy metal contaminated soils. Can. J. Microbiol., 42: 593-603. DOI: 10.1139/m96-080
24. Rulangaranga, Z.K., A.L. Mugasha, 2003. Effect of chromium uptake on the growth characteristics of Eichhornia crassipes (marts) sloms. Tanzania J. Sci., 29 : 109-125. http://www.ajol.info/viewarticle.php?jid=98\&id=1 6508\&layout=abstract

25. Ryan, R.P., K. Germain, A. Franks, D.J. Ryan and D.N. Dowling, 2008. Bacterial endophytes: Recent developments and applications. FEMS. Microbiol. Lett., 278: 1-9. http://www.ncbi.nlm.nih.gov/pubmed/18034833

26. Sambrook, J., E.F. Fritsch and T. Maniatis, 1989. Molecular Cloning: A Laboratory Manual. 2nd Edn., Cold Spring Harbor Laboratory Press Cold Spring Harbor , NY. ISBN: 13: 9780879695774

27. Schulz, B. and C. Boyle, 2006. What are Endophytes? In: Microbial Root Endophytes, Schulz, B.J.E., C.J.C. Boyle and T.N. Siever (Eds.). Springer-Verlag, Berlin, pp: 1-33. ISBN: 9783540335252

28. So, L.M., L.M. Chu and P.K. Wong, 2003. Microbial enhancement of $\mathrm{Cu}$ removal capacity of Eichhornia crassipes (Mart.). Chemosphere, 52: 1499-1503. http://www.ncbi.nlm.nih.gov/pubmed/12867181

29. Soltan, M.E. and M.N. Rashed, 2003. Laboratory study on the survival of water hyacinth under several conditions of heavy metal concentrations. Adv. Environ. Res., 7: 321-334. DOI: 10.1016/S1093-0191(02)00002-3

30. Taghavi, S., T. Barac, B. Greenberg, B. Borremans, J. Vangronsveld, D. Vander Leilie, 2005. Horizontal gene transfer to endogenous endophytic bacteria from poplar improved phytoremediation of toluene. Applied Environ. Microbiol., 71: 8500-8505. DOI: 10.1128/AEM.71.12.8500-8505.2005.

31. Trojanovska, S., M.L. Brotz and M. Bhave, 1997. Detection of heavy metal ion resistance genes in Gram-positive and Gram-negative bacteria isolated from a lead-contaminated site. Biodegradation, 8: 113-124. http://www.ncbi.nlm.nih.gov/pubmed/9342884

32. Wang, Y.J., M. Xiao, X.L. Geng, J.Y. Liu and J. Chen, 2007. Horizontal transfer of genetic determinants for degradation of phenol between the bacteria living in plant and its rhizosphere. Applied Microbiol. Biotechnol., 77: 733-739. http://cat.inist.fr/?aModele $=$ afficheN\&cpsidt $=1994$ 7022

33. Zhu, Y.L., A.M. Zayed, J.H. Qian, M. De Souza and N. Terry, 1999. Phytoremediation of trace elements by wetland plants: II water hyacinth. J. Environ. $\quad$ Q., $\quad$ 28: 339-344. http://direct.bl.uk/research/38/4C/RN056186530.ht $\mathrm{ml}$ ? source $=$ googlescholar 